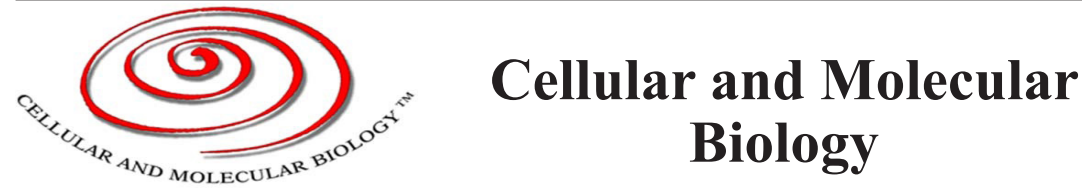

Aydin Cell. Mol. Biol.2016, 62 (14): 18-28

ISSN: $1165-158 \mathrm{X}$

doi: $10.14715 / \mathrm{cmb} / 2016.62 .14 .3$

\title{
Review
}

\section{Molecular talk of adipokines in dermatological diseases}

\author{
S. Aydin* \\ Department of Medical Biochemistry and Clinical Biochemistry, (Firat Hormones Research Group), Medical School, Firat University, Elazig, \\ Turkey
}

\begin{abstract}
Adipose tissue is not a passive tissue storing triglycerides, but one that releases hormones, enzymes, growth factors, and cytokines. Currently, known to release more than 600 adipokines, the adipose is an active tissue involved in energy homeostasis and serving paracrine, autocrine and endocrinal functions. Besides, some adipokines (irisin and ghrelin, for example) are synthesized in the sebaceous glands of the skin and play important roles in certain dermatological diseases. This review will provide a systemic overview of adipokines, focusing on their tissue and organ distribution, functions in biological systems, and roles in dermatological diseases. Additionally, the areas where adipokines can be used in dermatological diseases and their possible future roles will be presented.
\end{abstract}

Key words: Adipose tissue, endocrinal function, cutaneous diseases.

\section{Introduction}

Adipose (from the Latin word atleps, meaning fat) tissue is an active tissue where fat formed from connective tissue cells is stored, many hormones are synthesized and released, and numerous biochemical and physiological events are kept under strict control. The functions of the adipose tissue include maintenance of heat isolation, storage and secretion of fats, provision of padding around organs, protection of the body and organs against mechanic and external impacts (impact absorption), promotion of the harmony of nervous activities, preservation of the order of cells, storage of fatsoluble vitamins, synthesis and secretion of adipokines $(1,2)$, filling in of gaps between tissues, and forming a protective layer against external factors particularly in the sole of the foot and palm, among others.

The adipose tissue, $50 \%$ of which is composed of vascular elements, also includes fibroblasts, nerve elements, mast cells, pre-adipocytes, and mesenchymal cells, whose function is yet to be clarified. Since the fat taken into the cell pushes the nucleus to the side, the nucleus has an eccentric location. Based on the kind of fat droplets it includes, the adipose tissue is classified as white (unilocular) or brown (multilocular). As the white adipose tissue contains a single and large fat droplet, it appears as a "signet-ring". Cells forming the brown (multilocular) fat tissue, on the other hand, are composed of numerous small lipid droplets. Brown fat tissue cells also have numerous oval, global and fusiform mitochondria (Figure 1).

Although the gross anatomy of the human adipose tissue has not been shown in detail, white adipose tissue (WAT) is classified under two headings, as visceral and subcutaneous lipid stores. The adipose tissue underlying the skin or dermis is called the subcutaneous adipose tissue. In humans, subcutaneous adipose tissue is an extension of the dermal adipose tissue. In mice, dermal adipose tissue is separated by a layer of smooth muscles. The amounts of these two adipose tissues vary depending on age, sex, environmental temperature, diet, and metabolic conditions. In slender individuals, adipose tissue forms 8 to $10 \%$ of the body weight in males and 14 to $28 \%$ of the body weight in females. In obese individuals, however, the amount of adipose tissue is quadrupled, corresponding to 60 to $70 \%$ of body weight. White adipose tissue is generally found around the heart, blood vessels, eyes, mammary glands and bone marrow, while brown adipose tissue is located around the adrenal glands, kidneys, neck and mediastinum. Although these fat cells have different anatomic locations, they inevitably serve the same functions.

Over 100 skin diseases have described so far. Some skin diseases are minor, and others can be lifethreatening. Unfortunately however, there are only a few studies across the world examining the relationship between cutaneous diseases and adipocytes. Therefore, this study will first present a systematic overview of the main adipokines associated with human health and then a review of the studies exploring the relation between

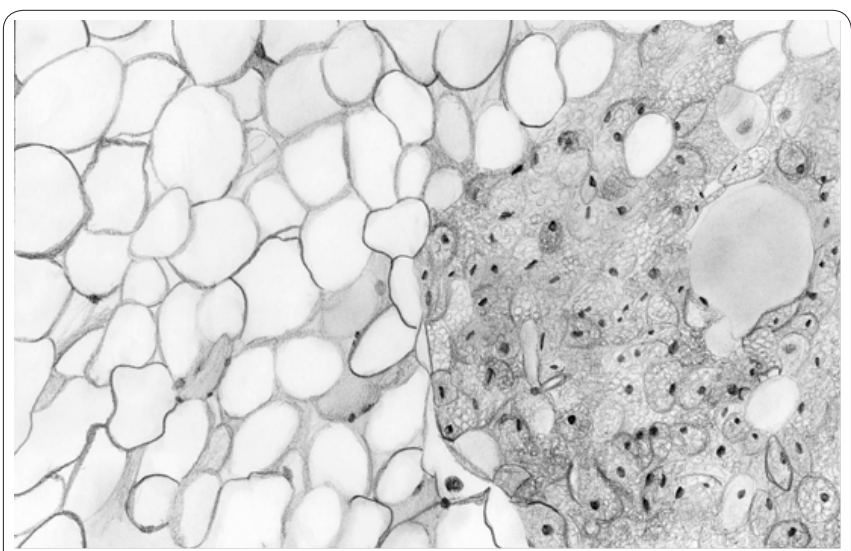

Figure 1. The general histological appearance of white and brown adipose tissue.

Received September 6, 2016; Accepted December 25, 2016; Published December 30, 2016 * Corresponding author: Prof. Dr. Suleyman Aydin, Firat University,
School of Medicine, Department of Medical Biochemistry (Firat Hormones
Research Group), 23119-Elazig, Turkey. Email: saydin1@hotmail.com

Copyright: (C) 2016 by the C.M.B. Association. All rights reserved. 
dermatological diseases (except tumors) and adipokines.

\section{Adipokines}

Molecules synthesized in the fat cells (proteins / protein factors) are generally called adipokines (3). Adipokines have multiple biological functions. Table 1 presents some adipocytes and the researchers who discovered them, as well as Table 2 shows the main biochemical functions of these molecules. In 1987, Cook et al. reported a molecule released from the fat tissue and called it adipcin/complement factor D (4). However, it was not until the discovery of leptin in 1994 (5) and of adiponectin in 1995 (6) that the possibility of fat tissue being an endocrine organ was acknowledged. Following the discovery of leptin and adiponectin in fat cells, these cells came under rigorous scrutiny, which resulted in the discovery of more than 600 adipokines. Some of these peptides were already known, but their presence in the fat cell was not until today and re-consideration of metabolic events $(7,8)$. Thus, the focus of the later parts of this review will be adipokines which are involved in metabolic events and dermatological diseases.

\section{Leptin}

Leptin is an adipose cell hormone. It is the first adipokine discovered by Dr. Jeffrey Friedman et al. in 1994 (21). Consisting of 167 amino acids, this fat cell hormone weighs $16 \mathrm{kDa}$. It has been derived from the Greek word leptos, meaning thin. Encoded by the obese (ob) gene, it is synthesized in many tissues, including the salivary glands and lipid and subcutaneous tissue. Leptin synthesis in the subcutaneous adipokine tissue is greater than that in the visceral adipokine tissue. The location and size of fat cells affect circulating leptin concentrations (37). As the body weight drops, circulating leptin concentrations are reduced. Women have higher leptin levels than men (38). Leptin levels are elevated

Table 1. The biological tissue/cell in which molecules synthesized by some adipocytes or affecting adipocytes, and the researchers who discovered them.

\begin{tabular}{|c|c|c|c|}
\hline \multirow{2}{*}{ Hormones } & \multicolumn{2}{|c|}{ First discovered in biological tissue/cell } & \multirow{2}{*}{ Researchers and year } \\
\hline & Tissue / Cell & Method & \\
\hline Fetuin-A & Serum & Centrifuging & Pederson et al. (1944) (9) \\
\hline Pancreatic Polypeptide & Pancreas & $\begin{array}{l}\text { Paper chromatography polyacrylamide } \\
\text { gel electrophoresis }\end{array}$ & Kimmel et al. (1968) (10) \\
\hline Motilin & Small intestines & Purification & Brown et al. (1971) (11) \\
\hline FABP 4 & $\begin{array}{l}\text { Intestinal mucosa, liver, myocardium, } \\
\text { adipose tissue, kidney }\end{array}$ & Protein synthesis & Ockner et al. (1972) (12) \\
\hline Copeptin & Neurohypophysis & $\begin{array}{l}\text { Gel filtration, chromatography, } \\
\text { electrophoresis }\end{array}$ & Holwerda et al. (1972) (13) \\
\hline Galanin & Intestinal extract & Thin layer chromatography & Tatemoto et al. (1978) (14) \\
\hline Neuropeptide Y & Hypothalamus & Fragmentation analysis & Tatemoto et al. (1982) (15) \\
\hline Adipsin & 3T3-F442A adipocytes & Electrophoresis & Cook et al. (1987) (4) \\
\hline Amylin & Pancreas islet (beta cells) & HPLC & Westermark et al. (1987) (16) \\
\hline ASP & Plasma & Electrophoresis & Cianflone et al. (1989) (17) \\
\hline Lipocalin 2 & Neutrophil gelatinase & Immunoblotting, immune-precipitation & Kjeldsen et al. (1999) (18) \\
\hline Visfatin & COS 7 and PA317 cells & cDNA library & Samal et al. (1994) (19) \\
\hline Leptin & Adipose & cDNA library & Zhang et al. (1994) (5) \\
\hline Adiponectin & 3T3-L1 adipocytes & DNA analysis, electrophoresis & Scherer et al. (1995) (6) \\
\hline Omentin & Intestinal paneth cells & $\begin{array}{l}\text { In situ hybridization, } \\
\text { Northern blot }\end{array}$ & Komiya et al. (1998) (20) \\
\hline Apelin & Stomach & RT-PCR, HPLC & Tatemoto et al. (1998) (21) \\
\hline Ghrelin & $\mathrm{X} / \mathrm{A}$ (ghrelin) cell & RIA, ELISA & Kojima et al. (1999) (22) \\
\hline Hepcidin & Blood ultrafiltrate & Mass spectrometry & Kraus et al. (2000) (23) \\
\hline Resistin & $\begin{array}{l}\text { Small intestine epithelium, bronchus } \\
\text { epithelium and white adipose tissues }\end{array}$ & $\begin{array}{l}\text { Sequence analysis IHC, Electrophoresis, } \\
\text { Western blot, Northern blot }\end{array}$ & Holcomb et al. (2000) (24) \\
\hline Preptin & TC6-F7 beta-cells & RİA, İHC & Bucham et al. (2001) (25) \\
\hline Salusin & cDNA library & Silico analysis & Shichiri et al. (2003) (26) \\
\hline Chemerin & Dendritic cells, macrophages & $\begin{array}{l}\text { Mass spectrophotometry } \\
\text { RT-PCR }\end{array}$ & Wittamer et al. (2003) (27) \\
\hline Desnutrin & 3T3-L1 adipocytes & Microarray analysis & Villena et al. (2004) (28) \\
\hline Obestatin & Stomach & Isolation & Zhang et al. (2005) (29) \\
\hline Nesfatin-1 & Hypothalamus & cDNA library & Oh-I et al. (2006) (30) \\
\hline Alarin & Neuroblastic tumor & RT-PCR & Santic et al. (2006) (31) \\
\hline Vaspin & Visceral white fatty tissue & PCR & Wada et al. (2008) (32) \\
\hline Adropine & Liver & $\begin{array}{l}\text { Microarray, } \\
\text { In situ hybridization }\end{array}$ & Kumar et al. (2008) (33) \\
\hline Irisin & Muscle cell & Western Blot & Boström et al. (2012) (34) \\
\hline
\end{tabular}

ASP: Acylation-stimulating protein, FABP 4: Fatty acid binding protein 4, IHC: Immunohistochemistry, RIA: Radioimmunoassay, ELISA: Enzyme-linked immunosorbent assay. 
Table 2. Major biochemical functions of molecules synthesized in certain adipocytes or affecting adipocytes $(7,35$ and 36$)$.

\begin{tabular}{ll}
\hline Molecules & Major Functions \\
\hline Adiponectin & Anti-diabetic, anti-atherogenic, anti-inflammatory, increases insulin tolerance \\
Adipsin & Activation of alternative complement pathway \\
Amylin & Regulation of insulin secretion and glucose metabolism \\
Apelin & Inhibition of insulin secretion \\
Desnutrin & Burning fat \\
Chemerin & Chemoreactant and regulator of adipogenesis \\
FAB4 & Impairment of myocardial contractility \\
Fetuin-A & Indicator of hepatosteatosis, inflammation and insulin resistance \\
Galanin & Cellular communication in central and peripheral nervous system, anti-microbial \\
Ghrelin & Starts feeding, regulates glucose metabolism \\
Hepcidin & Regulator of iron metabolism, anti-microbial \\
Cathepsins S, L, K & Regulation of adipose tissue mass and glucose metabolism \\
Leptin & Satiety signal, regulator of fertility, appetite and food intake \\
Lipocalin 2 & Indicator of inflammation and insulin resistance \\
Neuropeptide Y & Regulation of food intake \\
Irisin & Regulation of fat and glucose metabolism \\
Omentin & Increases insulin sensitivity and anti-inflammatory \\
Plasminogen activator inhibitor & Regulation of coagulation \\
Preptin & Regulation of insulin secretion and glucose metabolism \\
Resistin & Insulin resistance, inflammation and obesity \\
Salusin & Hypotensive, anti-microbial \\
Vaspin & Serine protease inhibitor, inhibition of food intake, improves hyperglycemia \\
Visfatin & Regulation of pancreatic beta cell functions \\
\hline FAB : Fatty acid &
\end{tabular}

FAB4: Fatty acid binding protein 4.

by proinflammatory cytokines (TNF), insulin, cortisol, overeating, glucose level, glucocorticoids and estrogen, and reduced by hunger, testosterone, growth hormone, cold, $\beta$-adrenergic agonists, epinephrine and free fatty acids.

Leptin regulates a number of biochemical and physiological systems and events, including the sympathetic nervous system, reproduction, bone metabolism, wound recovery, energy homeostasis, hematopoiesis, angiogenesis, immune and inflammatory response, and regulation of the gastrointestinal functions. Defects in the leptin gene or receptor results in the loss of control over eating and appetite. Besides, sympathetic activity and insulin resistance are reduced. Fulfilling all these functions by inhibiting the orexigenic (appetite-stimulating) signals and activating anorexigenic (appetite-inhibiting) signals in the hypothalamus, leptin keeps body weight under control.

\section{Adiponectin}

Adiponectin (GBP28, adipoQ, ACRP30) is a collagen-like plasma protein composed of 248 amino acids and weighing $30 \mathrm{kDa}(6)$. With a plasma concentration ranging between 5 and $30 \mu \mathrm{g} / \mathrm{mL}$, this protein of adipose origin has the highest circulating concentration among the known adipokines. Adiponectin affects estrogen, testosterone, fasting plasma insulin level, and diet concentrations. It has two primary receptors, one in the skeletal muscle (Adipo R1) and the other in the hepatic tissue (Adipo R2) (39). This adipokine regulating the energy balance and glucose and lipid metabolisms is correlated with insulin sensitivity and is elevated in response to insulin. It regulates the energy balance through muscle and liver tissues by increasing insulin sensitivity. Although it inhibits the gluconeoge- netic enzymes and glucose production, it does not have any impact on glucose intake, glycolysis and glycogen synthesis. Adiponectin also exercises anti-diabetic, antiapoptotic, anti-inflammatory (TNF- $\alpha$ ), anti-atherogenic (suppressing the foam cells of macrophages), and anti-oxidative effects.

\section{Ghrelin}

Discovered in 1999, this hormone is also known as the appetite hormone (22). The key feature of ghrelin is that, although it has a peptide structure, it does not contain amino acids. This feature is not found in any other peptide hormone. After ghrelin is synthesized in the ribosomes as a peptide hormone, either an eight-carbon (octanoic acid) fatty acid or a ten-carbon saturated fatty acid or a ten-carbon unsaturated fatty acid (with a double bond) is bound to its third amino acid serine (threonine in frogs (40) at the $\mathrm{N}$ terminal through posttranslational modification. Ghrelins with bound fatty acids are called acylated ghrelins. The bonding of these fatty acids to ghrelins was reported to be directly related to the amounts of dietary fat intake. The fatty acids in the ghrelins are severed by proteases. Ghrelins without fatty acids are called desacyl ghrelins.

Although the primary site of synthesis of this hormone was reported to be the X/A cells in the fundus part of the stomach, it is also synthesized in many other peripheral tissues including the adipose and cutaneous tissues (41). The main function of the hormone is to stimulate hunger. Therefore, its levels reach a peak immediately before meals. It has lower circulating levels in overweight individuals and higher levels in thin ones (42). It has been claimed that the main the reason why it has higher levels in the circulation of slim individuals is to lead the individual to eat so that s/he can reach a nor- 
mal weight. Besides regulating appetite, ghrelin is also responsible for the release of the growth hormone. Additionally, it serves anti-inflammatory, anti-microbial, and anti-oxidant functions.

\section{Plasminogen activator inhibitor-1}

This molecule, which is a serine protease inhibitor, is found in the adipose tissue of rodents (43). Later studies showed its presence in human adipose tissue (including the pre-adipose tissue). Omental fatty tissue contains more plasminogen activator inhibitor-1 than the subcutaneous fat tissue. Plasminogen activator inhibitor-1 in the omental fat tissue is induced by cytokines and angiotensin II. Currently, it is not known why omental adipose tissue has more plasminogen activator inhibitor-1 than the subcutaneous fat tissue.

\section{Hepcidin}

Hepcidin is synthesized in the ribosomes as a prepro-hormone. Consequently, this hormone is found in biological fluids as a pre-pro-hormone (with 84 amino acids), pro-hormone (with 60 amino acids) and hormone (with 25 amino acids). Urine was reported to contain hepcidin molecules with 20 and 22 amino acids. Saliva and milk also have hepcidin in them. A pro-hormone convertase molecule called "furin" mediates the conversion of pro-hormone hepcidin to hepcidin (44). Hepcidin was originally named LEAP-1 (23), but later renamed as hepcidin upon the discovery of its association with inflammation (45). The hepcidin gene located on the chromosome 19 is called HAMP. The principal site of hepcidin synthesis is the liver. However, recent studies have shown that it is also synthesized in the salivary gland, fat tissue, mammary tissue, and myeloid cells (against bacterial pathogens). This peptide hormone is removed from the cell through urine. Its major function is to reduce iron absorption in the small intestines (46). Additionally, Sow et al. have reported that it prevents the reproduction of the micro-organism by causing structural damage in M. tuberculosis and thus has an anti-microbial character (47). Later studies have shown that it not only prevents the reproduction of a number of bacteria including $E$. coli, but also has anti-fungal effects. Hepcidin synthesis in the liver is reduced in cases of hypoxia, increased erythropoietic activity and decreased ferritin amounts. Hepcidin receptor is called ferroportin. A basolateral transmembrane protein, ferroportin is found mainly in the reticuloendothelial macrophages, liver, placenta and intestinal tissues. When ferroportin on the cell surface is reduced, iron passage to the plasma is curtailed.

\section{Resistin}

This hormone released from the adipose tissue was discovered in 2000 by two independent research teams (Steppan and colleagues, 1998; Holcomb and colleagues) (24) while researching the thiazolidinedione class of medications. The hormone was called FIZZ1 by Holcomb and colleagues and FIZZ2 by Steppan and colleagues (48). Consisting of 108 amino acids, resistin has a molecular weight of $12.5 \mathrm{kDa}$ and is rich in cyste- ine. The hormone was named by an international committee as resistin from among the alternative names of FIZZ1, FIZZ3, ADSF, RELM, adipophilin and RETN1, due to its resistance against insulin. As the adipose mass increases in the organism, so do the resistin amounts. Females have higher levels of resistin in circulation than males. The circulating levels of resistin are reduced by anti-diabetic drug use.

\section{Visfatin}

Visfatin is composed of 491 amino acids and weighs $52 \mathrm{kDa}$. Studies have reported abundant synthesis of visfatin in the visceral fat tissue. When the adipose mass of the organism increases, visfatin levels show a parallel increase (49). In humans visfatin amounts are directly correlated with visceral fat mass, type 2 diabetes and metabolic syndrome (50). This hormone exercises insulin-like effects on glucose and lipid homeostasis. It speeds up triglyceride synthesis from glucose, and thus triggers adipogenesis. It has been suggested that use of visfatin at pharmacological doses can benefit the potential treatment of diabetes patients. Inflammation, hypoxia and hyperglycemia elevate visfatin levels, while reducing the levels of somatostatin and insulin (51).

\section{Omentin}

It has two main forms in the circulation as omentin-1 and omentin-2. Omentin- 1 and Omentin- 2 are $83 \%$ homologous. Although its presence was first identified in the Paneth cells of the liver (20), it was discovered in the omental fat tissue in 2003, using the C DNA library (52). Consisting of 313 amino acids, it weighs $35 \mathrm{kDa}$. Visceral fat tissue contains more omentin than subcutaneous and mature adipose tissues. Omentins are expressed in a variety of tissues, among which are epicardial adipose tissue, thymus, ovaries, lungs, colon, small intestines, placenta, reticulocytes, and endothelial cells. It has been claimed to protect the intestines against pathogenic bacteria and to be involved in the regulation of glucose (53). Omentin also functions as a vasoconstrictor, but its role in obesity is yet to be clarified.

\section{Chemerin}

Described in 2003, chemerin is composed of 131137 amino acids (27). Having an anti-microbial character, chemerin serves in glucose regulation, as well as the regulation of vascular inflammation response. However, its biological functions have not been fully recognized yet. Although it is synthesized abundantly in the keratinocyte cells of healthy skin, its synthesis is reduced in psoriasis (54). Being synthesized in the epidermis layer of the skin as well, chemerin has been suggested to be a critical peptide protecting the skin against pathogenic micro-organisms due to its anti-microbial effects (55).

\section{Vaspin}

Vaspin, composed of 392-395 amino acids, was identified in 2008 (32). Belonging to the family of serine protease inhibitors, vaspin regulates glucose by increasing insulin sensitivity. It inhibits the expression of 
pro-inflammatory adipocytes. Although it also has a part in controlling food intake, the mechanisms by which it does so are not certain yet.

\section{Neuropeptide family}

Neuropeptide Y (NPY), peptide YY (PYY) and pancreatic polypeptide (PPs) resemble each other structurally, and contain 36 amino acids (56). These three peptides serve many biological functions which include memory and learning operations, elevating water and food intake, inhibition of glutamatergic and noradrenergic synaptic transmission, reduced sexual action, changes in the circadian rhythm and induction of hypothermia. In addition, NPY has been reported to inhibit proliferation in keratinocytes (57). NPY expression was identified in the cutaneous lesions of atopic dermatitis patients.

\section{Apelin}

Apelin, another adipokine, was first described in 1998 by Tatemoto et al. in the bovine stomach juice (21). Apelins first develop as pro-peptides with 77 amino acids. From these pro-peptides, apeline-36, apelin-31, apelin-28, apelin-19, apelin-17, apelin-16, apelin-15, apelin-13, apelin-12 and pyroglutaminized apelin-13 are formed through posttranslational modification. Apart from the stomach, apelins were reported to be synthesized and to have receptors in many tissues such as the heart, lung, kidney, liver, adipose tissue, gastrointestinal tract, brain, adrenal gland, and endothelium (58). Plasma apelin levels are elevated in patients with obesity, insulin resistance and hyperinsulinemia. Apelin in adipose cells are inhibited by hunger and stimulated by food intake. For instance, intracerebro-ventricular administration of apelin to satiated rodents did not produce any effect on food intake, whereas it was reported to increase food intake of hungry animals in a dose-dependent manner. In other words, apelins regulate food intake. Among other physiological effects of apelins are diuresis, positive inotropic effect, fluid and glucose homeostasis, vessel formation, cell proliferation and regulation of immunity. They also decrease blood pressure. By reducing sodium and water intake, apelins inhibit the release of vasopressin (59).

\section{Galanin peptide family}

Galanin peptide family includes the galanin-message-associated-peptide, galanin-like peptide (GALP) and alarin. Galanin was first obtained from the porcine small intestine extracts in 1978 (14). It is synthesized profusely in the central nervous system and gastrointestinal system tissues. From the 123-amino-acid prepro-galanin, galanins with 29 (porcine) and 30 (human) amino acids are formed by post-translation. Bovine, mouse, human and porcine galanins show over $80 \%$ homology. In the gastrointestinal system, the highest amount of galanin synthesis takes place in the duodenum, which is followed by stomach, small intestines, and colon. It is directly connected with the central nervous system through cutaneous nerves (afferent and efferent nerves). Galanin is synthesized in and released from afferent nerves. There are galanin binding sites on the human skin, around dermal arteries and arterioles, and near the sweat glands. Keratinocytes synthesize small amounts of GALP and alarin adipocytes. Galanin is involved in the protection of cutaneous tissue from pathogenic bacteria (60).

\section{Amylin}

Consisting of 37 amino acids, this hormone is released from the pancreatic beta cells together with insulin at a proportion of 100:1. Amylin was discovered in 1987 by two independent groups of researchers. European researchers called the hormone islet amyloid polypeptide (IAPP), while the American researchers referred to it as amylin $(16,61)$. The hormone has a disulfide bond between amino acids 2 and 7, which is necessary for its biological activity. Amylin gives a sense of satiety and reduces gastric emptying. It also constrains post-prandial fluctuation in the glucose level, thereby exercising glycemic control. Amylin serves in the development of bones through calcitonin. It is a promising agent in the treatment of type 1 and type 2 diabetes. Amylin increases fat intake in 3T3-L1 adipose cells and is directly involved in the insulin resistance mechanism (62).

\section{Preptin}

Just like amylin, this peptide is released from the pancreatic beta cells with insulin. Isolated from the TC6-F7 pancreatic beta cells of rats in 2001, preptin is composed of 34 amino acids (25). It increases insulin secretion through glucose (25). Preptin contributes to bone development and prevents apoptosis in osteoblasts (63).

\section{Fatty acid binding proteins (FABPs)}

Fatty acid binding proteins belong to the family of lipid binding proteins. Its various forms from FABP1 to FABP12 have been defined. FABP1 is expressed in the liver, small intestines, pancreas, kidneys, lungs and stomach; FABP2 in the liver and small intestines; FABP3 in the heart and skeletal muscle, brain, kidneys, testes, adrenal glands, mammary glands, ovaries and brown fat tissue; FABP4 in the adipose tissues, macrophages, dendritic cells and skeletal muscle fibers; FABP5 in the skin, tongue, adipose cells, macrophages, dendritic cells, mammary glands, brain, stomach, small intestines, kidney, liver, lungs, heart, skeletal muscle, testes, retina, lenses, spleen and placenta; FABP6 in the ileum, ovarium, adrenal gland and stomach; FABP7 in the brain, central nervous system, glial cells, retina and mammary glands; FABP8 in the peripheral nervous system and Schwann cells; FABP9 in the testes, salivary glands and mammary glands; and FABP 12 in the retinoblastoma cells, retina, testis cells, cerebral cortex, kidneys and epididymis. Given this variety of forms, researchers should choose the one that is appropriate for their aims. For instance, a scientist examining cutaneous diseases should study FABP4 and FABP5, as these forms are produced by fat cells, and since FABP5 is synthesized in the skin, it seems more relevant to der- 
matological diseases (64).

\section{Lipocalin-2 [neutrophil gelatinase-associated lipo- calin (NGAL)]}

Lipocalin-2 is a member of the family of lipocalin proteins which also includes the fatty acid binding proteins. It prevents the reproduction of pathogenic bacteria and exercises growth hormone-like effects (65). It enhances the activity of MMP-9 which leads to the destruction of extracellular matrix and cell membrane. Recent studies have indicated that it can be a marker of kidney injury. Lipocalin-2 is expressed in the adipose cells, epithelium, colon, prostate, mammary glands and renal tubules. Stress, inflammation, infection, ischemia, Behcet's disease and psoriasis increase the synthesis of lipocalins (66).

\section{Cathepsins}

The term cathepsin is derived from the Greek word kathepsein, meaning digestion. Many cathepsins have been described, including B, C, F, H, K, L, O, S, V, X and $\mathrm{W}$ cathepsins. Lysosomal cathepsins are synthesized as pre-pro-enzymes in many human tissues including the adipose cells. Cathepsins regulate the glucose metabolism and adipose tissue mass (67).

\section{Fetuin-A}

Fetuin-A is an acute phase glycoprotein having a molecular weight of $60 \mathrm{kDa}$ and is synthesized primarily in the liver (hepatocytes) and adipose cells. Binding to insulin receptors in the muscle and fat tissue, it inhibits the activity of insulin receptor tyrosinase activity (68). It shows the steatosis in the liver and is a marker of both inflammation and insulin resistance. It has also been associated with the progression of cancer (69).

\section{The cutaneous structure and the adipokines synthe- sized in the skin}

Covering the body surface and fulfilling vital functions, the skin is composed of the layers of epidermis, dermis and subcutis. Keratinocytes (squamous cells) are the basic cells of the epidermis. Besides, Merkel cells, Langerhans cells and melanocytes are reported to be found in the dermis. The general histological appearance of the skin is presented in Figure 2. Squamous cells originate from the ectoderm and synthesize keratin, which is the primary protein of stratum corneum, hair, and nails. Epidermis is formed from the basal stratum (Str. Germinativum), stratum spinosum (Malpighian or Prickle layer), granular stratum (Str. Ganulosum) and stratum corneum (keratinized layer, horny layer).

The dermis layer of the skin is composed of elastic, reticular fibrils and collagen connective tissue. Dermis papillae extend into epidermis like the fingers of a glove. The extensions of the epidermis towards the dermis, on the other hand, are called "rete ridges".

The subcutis (Panniculus) layer lies below the dermis. This layer consists of lobules formed from adipokine cells separated by fibrous septa. This stratum of the skin protects the internal organs from external trau- mas. The subcutis stratum serves as a storage for some hormones. Hair, apocrine glands, eccrine sweat glands, nails and sebaceous glands are the other structures of the skin (70).

Studies in the last two decades have revealed that the skin is not only a cover veiling the skin, but also that the epidermis, beyond being a static barrier, is a critical endocrine organ serving endocrine and exocrine functions (71).

Epidermal cells synthesize neuropeptide Y (NPY), peptide YY (PYY), and pancreatic polypeptide, and these molecules have receptors in the skin. NPY prevents the accumulation of cAMP which increases upon induction of forskolin in keratinocytes. Put differently, NPY inhibits keratinocyte proliferation. Likewise, NPY and PYY irreversibly inhibit the reproduction of pathogenic micro-organisms in the human skin (72). Epidermis layer also synthesizes profuse amounts of galanin. Besides, FABP5 was reported to be synthesized by the skin and adipose tissue. Although this much is known about these molecules being synthesized in the skin, it is still not clear what functions they serve there.

Irisin, which converts the white adipose tissue into brown adipose tissue, was first reported to be synthesized in the skeletal muscle (34), and then in the smooth muscles, fat tissue (73) and cutaneous sebaceous glands (74). The key smooth muscle of the skin, arrector pilorum is attached to the hair follicle under the sebaceous gland. Besides, the skin synthesizes a molecule called dermcidin (75), which has an anti-microbial and endocrine character. Apart from these, ghrelin hormone was reported to be synthesized by the skin (76). Similarly, the synthesis of the chemerin molecule takes place in the epidermis layer (55). These hormones are also adipokines. As for the other adipokines, it is yet to be shown whether they are synthesized in the skin or not, and this remains a significant topic for research.

Furthermore, although there are innumerable skin

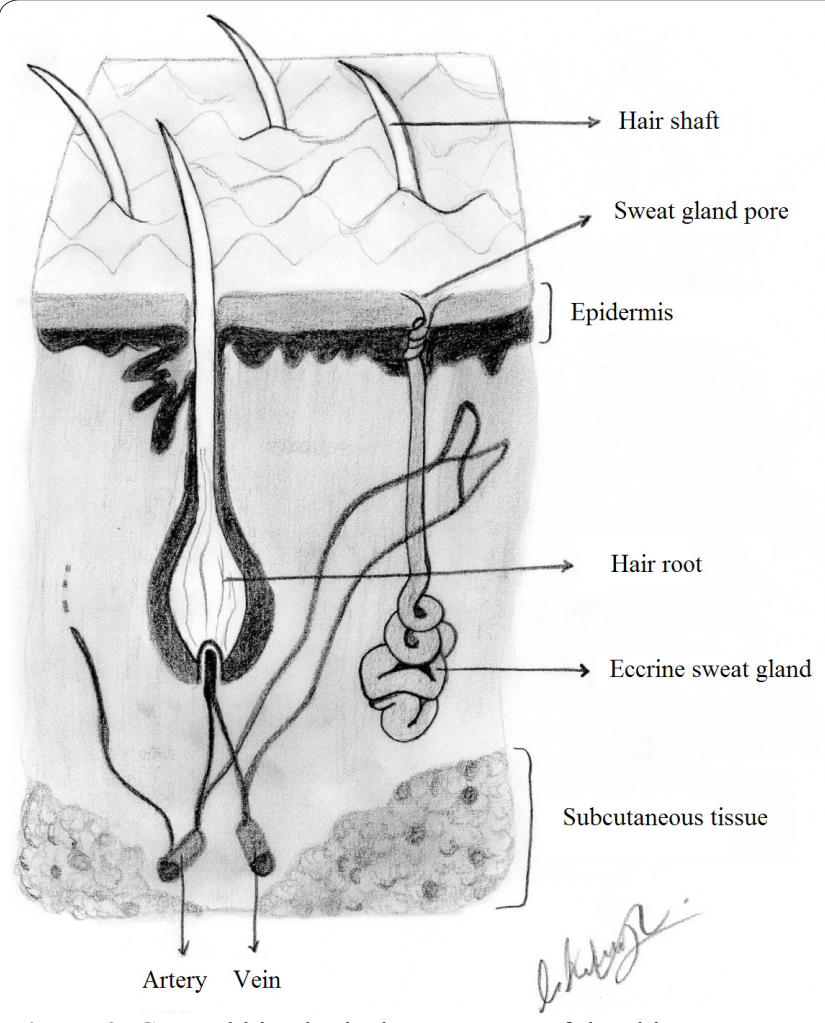

Figure 2. General histological appearance of the skin. 
diseases, such as acne, skin allergies, skin cancer, stretch marks, freckles, boils, eczema, baldness, wrinkles, rash, spots, acne vulgaris marks, callus, alopecia, beard inflammation, cellulitis, psoriasis, wart, carbuncle, vitiligo, herpes, scabies, erysipelas, to name a few, studies examining how they are related to adipokines are scarce. The rest of this review addresses the studies investigating the relations between adipokines (with the exception of interleukins, which are important adipocytes) and cutaneous diseases.

\section{Cutaneous diseases and adipokines}

\section{Acanthosis nigricans}

Benign acanthosis nigricans is usually associated with obesity. In this disease, leptin and resistin adipokines are elevated, while adiponectin is reduced (77).

\section{Psoriasis}

It is not clear whether there is a relationship between psoriasis and adiponectin, although adiponectin was reported to increase in psoriasis $(78,79)$. While serum retinol-binding protein 4 (RBP4), preptin and amylin decrease, serum leptin, visfatin, apelin, ghrelin, resistin and high-molecular-weight adiponectin and total adiponectin levels increase in this disease and these increases can be reversed by treatment (cyclosporine) (79). No consensus has been reached on the relationship between neuropeptide $\mathrm{Y}$ and omentin levels, and psoriasis. Although omentin amounts generally increase in psoriasis, one study reported a decrease (80). There is also no consensus the relationship between newly discovered adipokine-myokine, irisin and psoriasis $(81,82)$.

\section{Systemic sclerosis}

Patients with systemic sclerosis have higher levels of apelin and resistin $(83,84)$. In the early period, apelin levels were reported to be even higher. Adiponectin and leptin levels, on the other hand, were found lower in systemic sclerosis (85). Still, active systemic sclerosis patients have lower leptin levels than inactive ones (86). Additionally, it was reported that patients in the premenopausal period had higher leptin values than those in the post-menopausal period (87). Omentin levels are also found lower in this disease (88).

\section{Behcet's Disease}

Prohepcidin, hepcidin, salusin alpha, preptin and amylin amounts are reduced, whereas salusin-beta levels are elevated in Behcet's disease (89).

\section{Acne vulgaris}

Desnutrin, a recently discovered adipokine, was reported to be lower in this disease (90). The course of adipokines in various dermatological disease can be found in Table 3. Although there are numerous dermatological diseases, as the table shows, studies usually address the relations between adipokines and the diseases that are the most common in societies and that cause the major cosmetic problems. Given that the skin is a critical endocrine organ and certain adipokines are synthesized in the skin, it is obvious that the skin is bound to provide a prolific area of research.

What should be known when analyzing adipokines

\section{in biological fluids}

MEROPS data show that the human genome contains over 700 proteases. Peptide/protein hormones are rapidly broken down by cellular proteases. Since adipokines have peptide/protein structure, when they are being studied, protease inhibitors must be used to protect them from proteases. In general, use of $500 \mathrm{KIU}$ of protease inhibitor (aprotinine, for insntance) per milliliter of biological samples is recommended. Adipokines can be measured by enzyme-linked immunosorbent assay (ELISA) and radioimmunoassay (RIA) methods. If adipokines are to be studied in tissue samples, the tissue must be boiled in a water bath for 5 to 10 minutes to inactivate proteases. Thus, these samples can be kept stable at -20 or $-80^{\circ} \mathrm{C}$ for years $(115)$.

\section{Conclusion and future directions}

The adipose tissue, the weight of which corresponds to $20 \%$ of the body weight, secretes more than 600 adipokines $(7,8)$. The adipokines secreted from and synthesized by adipose cells have attracted growing interest over the last two decades and it seems that they will continue to do so in the future. The patho-physiology and biochemistry of the adipose tissue is of particular concern not only to academic researchers, but also physicians providing routine health care services, as at present, beyond being a storage for fats, the adipose tissue is an endocrinal organ where new hormones are being discovered.

Even though this endocrinal organ is explored extensively by biochemists, physiologists and endocrinologists, it has not come under the close examination of dermatologists, and consequently, there are few scientific studies about it in the field of dermatology. It is true that the real cause of many dermatological diseases is not known yet; still, some of them are recognized to be directly connected with inflammation and to involve endocrinal disorders. Considering that adipose tissue comprises $20 \%$ of body weight and a significant portion of fats accumulate in the subcutaneous tissue and many anti-inflammatory molecules and hormones are synthesized in and secreted from the adipose tissue, there is an obvious need for dermatologists to uncover the relations between dermatological diseases and adipokines. The discovery of adipokines connected with dermatological diseases will have strong implications for treatment, and thus will contribute to the elimination of many cosmetic problems.

\section{Acknowledgments}

I would like to extend my sincerest thanks to trainee Hacer Karabektaş, M.D. who produced charcoal drawings of the figures, Operator Doctor Suna Aydin, and dermatologist Prof. Dr. Demet Cicek who read the article with a critical eye.

\section{References}

1. Cinti S. The Adipose Organ. In: Fantuzzi G, Mazzone T, (Eds.) Adipose Tissue and Adipokines in Health and Disease. $1^{\text {st }}$ ed. New Jersey: Humana Press Inc; 2007, p.3-19.

2. Hauner H. Symposium on 'Biology of obesity' Secretory factors from human adipose tissue and their functional role. Proceedings of 
Table 3. How hormones synthesized in adipocytes or affecting adipocytes are altered in dermatological diseases.

\begin{tabular}{|c|c|c|c|c|}
\hline Dermatosis & Hormone & Sample - method & Outcome & Researchers \\
\hline \multirow{15}{*}{ Psoriasis } & Adiponectin & Plasma - ELISA & $\uparrow$ & Kaur et al. (2008) (91) \\
\hline & Adiponectin & \multirow[t]{2}{*}{ Serum-ELISA } & $\begin{array}{l}\uparrow \\
\downarrow \\
\downarrow \\
\downarrow\end{array}$ & $\begin{array}{l}\text { Ozdemir et al. (2012) (79) } \\
\text { Baran et al. (2014) (92) } \\
\text { Xue et al. (2012) (93) } \\
\text { Campanati et al. (2015) (94) }\end{array}$ \\
\hline & Apelin & & $\uparrow$ & Dertlioglu et al. (2013) (95) \\
\hline & Leptin & Serum-ELISA & $\begin{array}{l}\downarrow \\
\uparrow \\
\uparrow \\
\uparrow \\
\uparrow\end{array}$ & $\begin{array}{l}\text { Baran et al. (2014) (92) } \\
\text { Campanati et al. (2015) (94) } \\
\text { Xue et al. (2012) (93) } \\
\text { Ozdemir et al. (2012) (79) }\end{array}$ \\
\hline & \multirow{3}{*}{ Omentin } & $\begin{array}{l}\text { Skin, Serum - ELISA, } \\
\text { IHC }\end{array}$ & $\downarrow$ & Zhang et al. (2015) (96) \\
\hline & & $\begin{array}{l}\text { Serum- ELISA, RT- } \\
\text { PCR, } \\
\text { Electrophoresis }\end{array}$ & $\downarrow$ & Turan et al. (2014) (97) \\
\hline & & Serum-ELISA & $\begin{array}{l}\uparrow \\
\downarrow \\
\downarrow\end{array}$ & $\begin{array}{l}\text { Xue et al. (2012) (54) } \\
\text { Ismail et al. (2012) (98) } \\
\text { Takahashi et al. (2013) (99) }\end{array}$ \\
\hline & Visfatin & Serum - ELISA & $\uparrow$ & $\begin{array}{l}\text { Campanati et al. (2015) (94) } \\
\text { Ismail et al. (2012) (98) }\end{array}$ \\
\hline & Resistin & Serum-ELISA & $\begin{array}{l}\uparrow \\
\uparrow \\
\uparrow \\
\uparrow \\
\uparrow \\
\leftrightarrow\end{array}$ & $\begin{array}{l}\text { Campanati et al. (2015) (94) } \\
\text { Takahashi et al. (2013) (99) } \\
\text { Gisondi et al. (2013) (100) } \\
\text { Ozdemir et al. (2012) (79) } \\
\text { Xue et al. (2012) (54) }\end{array}$ \\
\hline & Ghrelin & Serum-ELISA & $\begin{array}{c}\uparrow \\
\uparrow\end{array}$ & $\begin{array}{l}\text { Ozdemir et al. (2012) (79) } \\
\text { Ucak et al. (2014) (76) }\end{array}$ \\
\hline & Amylin & Serum-ELISA & $\downarrow$ & Dogan et al. (2014) (101) \\
\hline & Chemerin & Serum-ELISA & $\uparrow$ & $\begin{array}{l}\text { Gisondi et al. (2013) (100) } \\
\text { Xue et al. (2012) (54) }\end{array}$ \\
\hline & $\begin{array}{l}\text { FABP } 4 \\
\text { Hepcidin }\end{array}$ & $\begin{array}{l}\text { İHK, Northern blot } \\
\text { Serum - ELISA }\end{array}$ & $\overleftrightarrow{\leftrightarrow}$ & $\begin{array}{l}\text { Kuijpers et al. (1997) (102) } \\
\text { Dilek et al. (2014) (103) }\end{array}$ \\
\hline & Lipocalin 2 & $\begin{array}{l}\text { Serum, Skin biopsy- } \\
\text { ELISA }\end{array}$ & $\leftrightarrow$ & El-Hadidi et al. (2014) (66) \\
\hline & $\begin{array}{l}\text { Neuropeptide Y } \\
\text { Preptin }\end{array}$ & $\begin{array}{l}\text { Plasma - RIA } \\
\text { Serum - ELISA }\end{array}$ & $\stackrel{\leftrightarrow}{\downarrow}$ & $\begin{array}{l}\text { Reich et al. (2007) (104) } \\
\text { Dogan et al. (2014) (101) }\end{array}$ \\
\hline $\begin{array}{l}\text { Allergic contact } \\
\text { dermatitis }\end{array}$ & Adiponectin & Serum-ELISA & $\uparrow$ & Kaur et al. (2014) (105) \\
\hline Atopic dermatitis & Neuropeptide Y & Plasma - RIA & $\begin{array}{l}\uparrow \\
\uparrow \\
\uparrow\end{array}$ & $\begin{array}{l}\text { Salomon et al. (2008) (106) } \\
\text { Hodeib et al. (2010) (107) }\end{array}$ \\
\hline Dermatitis & Leptin & Plasma-ELISA & $\leftrightarrow$ & Kaur et al. (2014) (105) \\
\hline \multirow{3}{*}{ Behçet's disease } & Amylin & \multirow{3}{*}{$\begin{array}{l}\text { Serum - ELISA } \\
\text { Serum, Saliva /Salivary } \\
\text { gland- ELISA, İHK } \\
\text { Leptin G2548A - ELISA } \\
\text { Serum - ELISA } \\
\text { Serum-ELISA } \\
\end{array}$} & $\downarrow$ & Dogan et al. (2014) (101) \\
\hline & Hepcidin & & $\downarrow$ & Cicek et al. (2014) (108) \\
\hline & $\begin{array}{l}\text { Leptin } \\
\text { Preptin } \\
\text { Salusin }\end{array}$ & & $\begin{array}{c}\stackrel{\leftrightarrow}{\downarrow} \\
\text { Sal- } \alpha \downarrow, \text { Sal- } \beta \uparrow\end{array}$ & $\begin{array}{l}\text { Aydin et al. (2007) (109) } \\
\text { Dogan et al. (2014) (101) } \\
\text { Erden et al. (2014) (89) }\end{array}$ \\
\hline Skin tag's & $\begin{array}{l}\text { Leptin } \\
\text { Leptin }\end{array}$ & $\begin{array}{l}\text { Serum-ELISA } \\
\text { Plasma-ELISA }\end{array}$ & $\stackrel{\leftrightarrow}{\uparrow}$ & $\begin{array}{l}\text { Gorpelioglu et al. (2009) (110) } \\
\text { El Safoury et al. (2011) (111) }\end{array}$ \\
\hline Acne vulgaris & $\begin{array}{l}\text { Desnutrin } \\
\text { Ghrelin }\end{array}$ & $\begin{array}{l}\text { Serum-ELISA } \\
\text { Serum, pilosebaceous } \\
\text { tissues - ELISA, İHK }\end{array}$ & $\begin{array}{l}\downarrow \\
\downarrow\end{array}$ & $\begin{array}{l}\text { Demir et al. (2014) (90) } \\
\text { Cicek et al. (2015) (112) }\end{array}$ \\
\hline $\begin{array}{l}\text { Benign cutaneous } \\
\text { tumors }\end{array}$ & Leptin & Skin biopsy - ELISA & $\uparrow$ & El Safoury et al. (2010) (113) \\
\hline $\begin{array}{l}\text { Polymyositis / } \\
\text { dermatomyositis }\end{array}$ & Neuropeptide Y & Plasma - RIA & $\uparrow$ & Liu et al. (2004) (114) \\
\hline Systemic sclerosis & $\begin{array}{l}\text { Omentin (Intelectin- } \\
\text { 1) }\end{array}$ & Serum - ELISA & $\downarrow$ & Miura et al. (2015) (88) \\
\hline Vitiligo & Neuropeptide Y & Plasma, Skin - RIA & $\uparrow$ & Tu et al. (2001) (93) \\
\hline
\end{tabular}

ELISA: Enzyme-linked immunosorbent assay; IHC: Immunohistochemistry; $\uparrow$ : increase; $\downarrow$ : decrease; $\leftrightarrow$ : constant; FABP4: Fatty acid binding protein 4; Sal- $\alpha$ : Salusin alpha; Sal- $\beta$ : Salusin beta.

the Nutrition Society 2005; 64:163-9.

3. Fasshauer M, Blüher M. Adipokines in health and disease. Trends Pharmacol Sci 2015; S0165-6147:00090-5.

4. Cook KS, Min HY, Johnson D, Chaplinsky RJ, Flier JS, Hunt $\mathrm{CR}$, et al. Adipsin: a circulating serine protease homolog secreted by adipose tissue and sciatic nerve. Science 1987; 237:402-5.

5. Zhang Y, Proenca R, Maffei M, Barone M, Leopold L, Friedman JM. Positional cloning of the mouse obese gene and its human homologue. Nature 1994; 372:425-32.

6. Scherer PE, Williams S, Fogliano M, Baldini G, Lodish HF. A novel serum protein similar to $\mathrm{C} 1 \mathrm{q}$, produced exclusively in adipocytes. J Biol Chem 1995; 270:26746-9.
7. Blüher M, Mantzoros CS. From leptin to other adipokines in health and disease: Facts and expectations at the beginning of the 21st century. Metabolism 2015; 64:131-45.

8. Lehr S, Hartwig S, Sell H. Adipokines: a treasure trove for the discovery of biomarkers for metabolic disorders. Proteomics Clin Appl 2012; 6:91-101.

9. Pederson KO. Fetuin, a new globulin isolated from serum. Nature $1944 ; 154: 575$.

10. Kimmel JR, Pollock HG, Hazelwood RL. Isolation and characterization of chicken insulin. Endocrinology 1968; 83:1323-30.

11. Brown JC, Mutt V, Dryburgh JR. The further purification of motilin, a gastric motor activity stimulating polypeptide from the mu- 
cosa of the small intestine of hogs. Can J Physiol Pharmacol 1971; 49:399-405.

12. Ockner RK, Manning JA, Poppenhausen RB, Ho WK. A binding protein for fatty acids in cytosol of intestinal mucosa, liver, myocardium, and other tissues. Science 1972; 177:56-8.

13. Holwerda DA. A glycopeptide from the posterior lobe of pig pituitaries. I. Isolation and characterization. Eur J Biochem 1972; 28:334-9.

14. Tatemoto K, Mutt V. Chemical determination of polypeptide hormones. Proc Natl Acad Sci U S A 1978; 75:4115-9.

15. Tatemoto K, Carlquist M, Mutt V. Neuropeptide Y--a novel brain peptide with structural similarities to peptide YY and pancreatic polypeptide. Nature 1982; 296:659-60.

16. Westermark P, Wernstedt C, Wilander E, Hayden DW, O'Brien TD, Johnson KH. Amyloid fibrils in human insulinoma and islets of Langerhans of the diabetic cat are derived from a neuropeptide-like protein also present in normal islet cells. Proc Natl Acad Sci U S A 1987; 84:3881-5.

17. Cianflone KM, Sniderman AD, Walsh MJ, Vu HT, Gagnon J, Rodriguez MA. Purification and characterization of acylation stimulating protein. J Biol Chem 1989; 264:426-30.

18. Kjeldsen L, Johnsen AH, Sengeløv H, Borregaard N. Isolation and primary structure of NGAL, a novel protein associated with human neutrophil gelatinase. J Biol Chem 1993; 268:10425-32.

19. Samal B, Sun Y, Stearns G, Xie C, Suggs S, McNiece I. Cloning and characterization of the cDNA encoding a novel human pre-Bcell colony-enhancing factor. Mol Cell Biol 1994; 14:1431-7.

20. Komiya T, Tanigawa Y, Hirohashi S. Cloning of the novel gene intelectin, which is expressed in intestinal paneth cells in mice. Biochem Biophys Res Commun 1998; 251:759-62.

21. Tatemoto K, Hosoya M, Habata Y, Fujii R, Kakegawa T, Zou $\mathrm{MX}$ et al. Isolation and characterization of a novel endogenous peptide ligand for the human APJ receptor. Biochem Biophys Res Commun 1998; 251:471-6.

22. Kojima M, Hosoda H, Date Y, Nakazato M, Matsuo H, Kangawa $\mathrm{K}$. Ghrelin is a growth-hormone-releasing acylated peptide from stomach. Nature 1999; 402:656-60.

23. Krause A, Neitz S, Mägert H, Schulz A, Forssmann W, SchulzKnappe P, et al. LEAP-1, a novel highly disulfide-bonded human peptide, exhibits antimicrobial activity. FEBS Lett 2000; 480:14750 .

24. Holcomb IN, Kabakoff RC, Chan B, Baker TW, Gurney A, Henzel W, et al. FIZZ1, a novel cysteine-rich secreted protein associated with pulmonary inflammation, defines a new gene family. EMBO J 2000; 19:4046-55.

25. Buchanan CM, Phillips AR, Cooper GJ. Preptin derived from proinsulin-like growth factor II (proIGF-II) is secreted from pancreatic islet beta-cells and enhances insulin secretion. Biochem J 2001; 360:431-9.

26. Shichiri M, Ishimaru S, Ota T, Nishikawa T, Isogai T, Hirata Y. Salusins: newly identified bioactive peptides with hemodynamic and mitogenic activities. Nat Med 2003; 9:1166-72.

27. Wittamer V, Franssen JD, Vulcano M, Mirjolet JF, Le Poul E, Migeotte I, et al. Specific recruitment of antigen-presenting cells by chemerin, a novel processed ligand from human inflammatory fluids. J Exp Med 2003; 198:977-85.

28. Villena JA, Roy S, Sarkadi-Nagy E, Kim KH, Sul HS. Desnutrin, an adipocyte gene encoding a novel patatin domain-containing protein, is induced by fasting and glucocorticoids: ectopic expression of desnutrin increases triglyceride hydrolysis. J Biol Chem 2004; 279:47066-75.

29. Zhang JV, Ren PG, Avsian-Kretchmer O, Luo CW, Rauch R, Klein C, et al. Obestatin, a peptide encoded by the ghrelin gene, opposes ghrelin's effects on food intake. Science 2005; 310:996-9.
30. Oh-I S, Shimizu H, Satoh T, Okada S, Adachi S, Inoue K, et al. Identification of nesfatin-1 as a satiety molecule in the hypothalamus. Nature 2006; 443:709-12.

31. Santic R, Fenninger K, Graf K, Schneider R, Hauser-Kronberger $\mathrm{C}$, Schilling $\mathrm{FH}$, et al. Gangliocytes in neuroblastic tumors express alarin, a novel peptide derived by differential splicing of the galaninlike peptide gene. J Mol Neurosci 2006; 29:145-52.

32. Wada J. Vaspin: a novel serpin with insulin-sensitizing effects. Expert Opin Investig Drugs 2008; 17:327-33.

33. Kumar KG, Trevaskis JL, Lam DD, Sutton GM, Koza RA, Chouljenko VN, et al. Identification of adropin as a secreted factor linking dietary macronutrient intake with energy homeostasis and lipid metabolism. Cell Metab 2008; 8:468-81.

34. Boström P, Wu J, Jedrychowski MP, Korde A, Ye L, Lo JC, et al. A PGC1- $\alpha$-dependent myokine that drives brown-fat-like development of white fat and thermogenesis. Nature 2012; 481:463-8.

35. Blüher M. Adipose tissue dysfunction contributes to obesity related metabolic diseases. Best Pract Res Clin Endocrinol Metab 2013; 27:163-77.

36. Blüher M. Importance of adipokines in glucose homeostasis. Diabetes Manage 2013; 3:389-400.

37. Skopková M, Penesová A, Sell H, Rádiková Z, Vlcek M, Imrich $\mathrm{R}$, et al. Protein array reveals differentially expressed proteins in subcutaneous adipose tissue in obesity. Obesity (Silver Spring) 2007; 15:2396-406.

38. McConway MG, Johnson D, Kelly A, Griffin D, Smith J, Wallace AM. Differences in circulating concentrations of total, free and bound leptin relate to gender and body composition in adult humans. Ann Clin Biochem 2000; 37:717-23.

39. Kharroubi I, Rasschaert J, Eizirik DL, Cnop M. Expression of adiponectin receptors in pancreatic beta cells. Biochem Biophys Res Commun 2003; 312:1118-22.

40. Kaiya H, Kojima M, Hosoda H, Koda A, Yamamoto K, Kitajima $\mathrm{Y}$, et al. Bullfrog ghrelin is modified by n-octanoic acid at its third threonine residue. J Biol Chem 2001; 276:40441-8.

41. Aydin S, Sahin I, Ozkan Y, Dag E, Gunay A, Guzel SP, et al. Examination of the tissue ghrelin expression of rats with diet-induced obesity using radioimmunoassay and immunohistochemical methods. Mol Cell Biochem 2012; 365:165-73.

42. Sahin I, Aydin S, Ozkan Y, Dagli AF, Akin KO, Guzel SP, et al. Diet-induced obesity suppresses ghrelin in rat gastrointestinal tract and serum. Mol Cell Biochem 2011; 355:299-308.

43. Larsson B. Obesity, fat distribution and cardiovascular disease. Int J Obesity 1991; 15:53-7.

44. Valore EV, Ganz T. Posttranslational processing of hepcidin in human hepatocytes is mediated by the prohormone convertase furin. Blood Cells Mol Dis 2008; 40:132-8.

45. Park C, Valore E, Waring A, Ganz T. Hepcidin, a urinary antimicrobial peptide synthesized in the liver. J Biol Chem 2001; 276:7806-10.

46. Nemeth E, Tuttle MS, Powelson J, Vaughn MB, Donovan A, Ward DM, et al. Hepcidin regulates cellular iron efflux by binding to ferroportin and inducing its internalization. Science 2004; 306:2090 $\square$.

47. Sow FB, Florence WC, Satoskar AR, Schlesinger LS, Zwilling BS, Lafuse WP. Expression and localization of hepcidin in macrophages: a role in host defense against tuberculosis. J Leukoc Biol 2007; 82:934-45.

48. Steppan CM, Brown EJ, Wright CM, Bhat S, Banerjee RR, Dai $\mathrm{CY}$, et al. A family of tissue-specific resistin-like molecules. Proc Natl Acad Sci U S A 2001; 98:502-6.

49. Kamińska A, Kopczyńska E, Bieliński M, Borkowska A, Junik $\mathrm{R}$. Visfatin concentrations in obese patients in relation to the presence of newly diagnosed glucose metabolism disorders. Endokrynol 
Pol 2015; 66:108-13.

50. Schindler K, Vila G, Hoppichler F, Lechleitner M, Luger A, Anderwald $\mathrm{C}$, et al. The impact of type 2 diabetes on circulating adipokines in patients with metabolic syndrome. Obes Facts 2012; 5:270-6.

51. Adeghate E. Visfatin: structure, function and relation to diabetes mellitus and other dysfunctions. Curr Med Chem 2008; 15:1851-62.

52. Yang R, Xu A, Pray J, Hu H, Jadhao S, Hansen B, et al. D. Cloning of omentin, a new adipocytokine from omental fat tissue in humans. Diabetes 2003; Suppl 1:A1.

53. Tan BK, Adya R, Farhatullah S, Lewandowski KC, O'Hare P, Lehnert $\mathrm{H}$, et al. Omentin-1, a novel adipokine, is decreased in overweight insulin-resistant women with polycystic ovary syndrome: ex vivo and in vivo regulation of omentin-1 by insulin and glucose. Diabetes 2008; 57:801-8.

54. Xue Y, Jiang L, Cheng Q, Chen H, Yu Y, Lin Y, et al. Adipokines in psoriatic arthritis patients: the correlations with osteoclast precursors and bone erosions. PLoS One 2012; 7:e46740.

55. Banas M, Zegar A, Kwitniewski M, Zabieglo K, Marczynska J, Kapinska-Mrowiecka M, et al. The expression and regulation of chemerin in the epidermis. PLoS One 2015; 10:e0117830.

56. Glover ID, Barlow DJ, Pitts JE, Wood SP, Tickle IJ, Blundell TL, et al. Conformational studies on the pancreatic polypeptide hormone family. Eur J Biochem 1984; 142:379-85.

57. Takahashi K, Nakanishi S, Imamura S. Direct effects of cutaneous neuropeptides on adenylyl cyclase activity and proliferation in a keratinocyte cell line: stimulation of cyclic AMP formation by CGRP and VIP/PHM, and inhibition by NPY through G proteincoupled receptors. J Invest Dermatol 1993; 101:646-51.

58. Charles CJ. Putative role for apelin in pressure/volume homeostasis and cardiovascular disease. Cardiovasc Hematol Agents Med Chem 2007; 5:1-10.

59. Aydin S, Eren MN, Sahin I, Aydin S. The role of apelins in the physiology of the heart. Protein Pept Lett 2014; 21:2-9.

60. Bauer JW, Lang R, Jakab M, Kofler B. Galanin family of peptides in skin function. Cell Mol Life Sci 2008; 65:1820-5.

61. Cooper GJ, Willis AC, Clark A, Turner RC, Sim RB, Reid KB, Purification and characterization of a peptide from amyloid-rich pancreases of type 2 diabetic patients. Proc Natl Acad Sci USA 1987; 84:8628-32.

62. Miegueu P, St-Pierre DH, Munkonda MN, Lapointe M, Cianflone K. Amylin stimulates fatty acid esterification in 3T3-L1 adipocytes. Mol Cell Endocrinol 2013; 366:99-107.

63. Cornish J, Callon KE, Bava U, Watson M, Xu X, Lin JM, et al. Preptin, another peptide product of the pancreatic beta-cell, is osteogenic in vitro and in vivo. Am J Physiol Endocrinol Metab 2007; 292:E117-22.

64. Smathers RL, Petersen DR. The human fatty acid-binding protein family: Evolutionary divergences and functions. Hum Genomics 2011; 5:170-91.

65. Steigedal M, Marstad A, Haug M, Damås JK, Strong RK, Roberts PL, et al. Lipocalin 2 imparts selective pressure on bacterial growth in the bladder and is elevated in women with urinary tract infection. J Immunol 2014; 193:6081-9.

66. El-Hadidi H, Samir N, Shaker OG, Otb S. Estimation of tissue and serum lipocalin-2 in psoriasis vulgaris and its relation to metabolic syndrome. Arch Dermatol Res 2014; 306:239-45.

67. Turk V, Stoka V, Vasiljeva O, Renko M, Sun T, Turk B, et al. Cysteine cathepsins: from structure, function and regulation to new frontiers. Biochim Biophys Acta 2012; 1824:68-88.

68. Mathews ST, Chellam N, Srinivas PR, Cintron VJ, Leon MA, Goustin AS, et al. Alpha2-HSG, a specific inhibitor of insulin receptor autophosphorylation, interacts with the insulin receptor. Mol Cell Endocrinol 2000; 164:87-98.
69. Luo Y, Yang C, Ye M, Jin C, Abbruzzese JL, Lee MH, et al. Deficiency of metabolic regulator FGFR4 delays breast cancer progression through systemic and microenvironmental metabolic alterations. Cancer Metab 2013; 1:21.

70. McGrath JA, Eady RAJ. Pope FM. Anatomy and Organization of Human Skin. In: Burns T, Breathnach S, Cox N, Griffiths C, (Eds.) Rook's Textbook of Dermatology. $7^{\text {th }}$ ed. Massachusetts: Blackwell Publishing Inc; 2004, p. 45-128.

71. Bauer JW, Lang R, Jakab M, Kofler B. Galanin family of peptides in skin function. Cell Mol Life Sci 2008; 65:1820-5.

72. Dumont Y, Bastianetto S, Duranton A, Breton L, Quirion R. Immunohistochemical distribution of neuropeptide Y, peptide YY, pancreatic polypeptide-like immunoreactivity and their receptors in the epidermal skin of healthy women. Peptides 2015; 70:7-16.

73. Aydin S. Three new players in energy regulation: preptin, adropin and irisin. Peptides 2014; 56:94-110.

74. Aydin S, Aydin S, Kuloglu T, Yilmaz M, Kalayci M, Sahin I, et al. Alterations of irisin concentrations in saliva and serum of obese and normal-weight subjects, before and after 45 min of a Turkish bath or running. Peptides 2013; 50:13-8.

75. Rieg S, Garbe C, Sauer B, Kalbacher H, Schittek B. Dermcidin is con-stitutively produced by eccrine sweat glands and is not induced inepidermal cells under inflammatory skin conditions. Br J Dermatol 2004; 151:534-9.

76. Ucak H, Demir B, Cicek D, Erden I, Aydin S, Dertlioglu SB, et al. Metabolic changes and serum ghrelin level in patients with psoriasis. Dermatol Res Pract 2014; 2014:175693.

77. Atwa M, Emara A, Balata M, Youssef N, Bayoumy N, Sherif A, et al. Serum leptin, adiponectin, and resistin among adult patients with acanthosis nigricans: correlations with insulin resistance and risk factors for cardiovascular disease. Int J Dermatol 2014; 53:e410-20.

78. Dikbas O, Tosun M, Bes C, Tonuk SB, Aksehirli OY, Soy M. Serum levels of visfatin, resistin and adiponectin in patients with psoriatic arthritis and associations with disease severity. Int J Rheum Dis 2016; 19:672-7.

79. Ozdemir M, Yüksel M, Gökbel H, Okudan N, Mevlitoğlu I. Serum leptin, adiponectin, resistin and ghrelin levels in psoriatic patients treated with cyclosporin. J Dermatol 2012; 39:443-8.

80. Takahashi H, Tsuji H, Honma M, Ishida-Yamamoto A, Iizuka H. Increased plasma resistin and decreased omentin levels in Japanese patients with psoriasis. Arch Dermatol Res 2013; 305:113-6.

81. Baran A, Myśliwiec H, Kiluk P, Świderska M, Flisiak I. Serum irisin levels in patients with psoriasis. J Dermatolog Treat. 2016; Article in press.

82. Bulur I, Kaya Erdogan H, Kocatürk E, Saracoglu ZN, Alataş Ö, Yildiz $\mathrm{P}$, et al. The role of irisin in the relationship between psoriasis and insulin resistance. G Ital Dermatol Venereol. 2016; Article in press.

83. Aozasa N, Asano Y, Akamata K, Noda S, Masui Y, Yamada D, et al. Serum apelin levels: clinical association with vascular involvements in patients with systemic sclerosis. J Eur Acad Dermatol Venereol 2013; 27:37-42.

84. Masui Y, Asano Y, Akamata K, Aozasa N, Noda S, Taniguchi T, et al. Serum resistin levels: a possible correlation with pulmonary vascular involvement in patients with systemic sclerosis. Rheumatol Int 2014; 34:1165-70.

85. Winsz-Szczotka K, Kuźnik-Trocha K, Komosińska-Vassev K, Kucharz E, Kotulska A, Olczyk K. Relationship between adiponectin, leptin, IGF-1 and total lipid peroxides plasma concentrations in patients with systemic sclerosis: possible role in disease development. Int J Rheum Dis 2016; 19:706-14.

86. Budulgan M, Dilek B, Dağ ŞB, Batmaz I, Yıldız İ, Sarıyıldız $\mathrm{MA}$, et al. Relationship between serum leptin level and disease 
activity in patients with systemic sclerosis. Clin Rheumatol 2014; 33:335-9.

87. Kotulska A, Kucharz EJ, Brzezińska-Wcisło L, Wadas U. A decreased serum leptin level in patients with systemic sclerosis. Clin Rheumatol 2001; 20300-2.

88. Miura S, Asano Y, Saigusa R, Yamashita T, Taniguchi T, Takahashi T, et al. Serum omentin levels: A possible contribution to vascular involvement in patients with systemic sclerosis. J Dermatol 2015; 42:461-6.

89. Erden I, Demir B, Uçak H, Cicek D, Dertlioğlu SB, Aydin S. Serum salusin- $\alpha$ and salusin- $\beta$ levels in patients with Behcet's disease. Eur J Dermatol 2014; 24:577-82.

90. Demir B, Ucak H, Cicek D, Aydin S, Erden I, Dertlioglu SB. Changes in serum desnutrin levels in patients with acne vulgaris. Eur J Dermatol 2014; 24:589-93.

91. Kaur S, Zilmer K, Kairane C, Kals M, Zilmer M. Clear differences in adiponectin level and glutathione redox status revealed in obese and normal-weight patients with psoriasis. Br J Dermatol 2008; 159:1364-7.

92. Baran A, Flisiak I, Jaroszewicz J, Swiderska M. Serum adiponectin and leptin levels in psoriatic patients according to topical treatment. J Dermatolog Treat 2015; 26:134-8.

93. Tu C, Zhao D, Lin X. Levels of neuropeptide-Y in the plasma and skin tissue fluids of patients with vitiligo. J Dermatol Sci 2001; 27:178-82.

94. Campanati A, Ganzetti G, Giuliodori K, Marra M, Bonfigli A, Testa R, et al. Serum levels of adipocytokines in psoriasis patients receiving tumor necrosis factor- $\alpha$ inhibitors: results of a retrospective analysis. Int J Dermatol 2015; 54:839-45.

95. Dertlioglu SB, Cicek D, Suleyman A. Increased serum apelin-12 and lipid profile in patients with and without psoriasis. Eur J Dermatol 2013; 23:885-6.

96. Zhang C, Zhu KJ, Liu JL, Xu GX, Liu W, Jiang FX, et al. Omentin-1 plasma levels and omentin-1 expression are decreased in psoriatic lesions of psoriasis patients. Arch Dermatol Res 2015; 307:4559.

97. Turan H, Yaykasli KO, Soguktas H, Yaykasli E, Aliagaoglu C, Erdem T, et al. Omentin serum levels and omentin gene Val109Asp polymorphism in patients with psoriasis. Int J Dermatol 2014; 53:601-5.

98. Ismail SA, Mohamed SA. Serum levels of visfatin and omentin-1 in patients with psoriasis and their relation to disease severity. Br J Dermatol 2012; 167:436-9.

99. Takahashi H, Tsuji H, Honma M, Ishida-Yamamoto A, Iizuka H. Increased plasma resistin and decreased omentin levels in Japanese patients with psoriasis. Arch Dermatol Res 2013; 305:113-6.

100. Gisondi P, Lora V, Bonauguri C, Russo A, Lippi G, Girolomoni G. Serum chemerin is increased in patients with chronic plaque psoriasis and normalizes following treatment with infliximab. Br J Dermatol 2013; 168:749-55.

101. Dogan FB, Cicek D, Aydin S, Dertlioglu SB, Halisdemir N, Ucak H, et al. Serum Preptin and Amylin Values in Psoriasis Vul- garis and Behçet's Patients. J Clin Lab Anal 2016; 30:165-8.

102. Kuijpers AL, Bergers M, Siegenthaler G, Zeeuwen PL, van de Kerkhof PC, Schalkwijk J. Skin-derived antileukoproteinase (SKALP) and epidermal fatty acid-binding protein (E-FABP): two novel markers of the psoriatic phenotype that respond differentially to topical steroid. Acta Derm Venereol 1997; 77:14-9.

103. Dilek N, Dilek AR, Sahin K, Kaklıkkaya N, Saral Y. Hepcidin expression in psoriasis patients. Indian J Dermatol 2014; 59:630.

104. Reich A, Orda A, Wiśnicka B, Szepietowski JC. Plasma concentration of selected neuropeptides in patients suffering from psoriasis. Exp Dermatol 2007; 16:421-8.

105. Kaur S, Zilmer K, Leping V, Zilmer M. Allergic contact dermatitis is associated with significant oxidative stress. Dermatol Res Pract 2014; 2014:415638.

106. Salomon J, Baran E. The role of selected neuropeptides in pathogenesis of atopic dermatitis. J Eur Acad Dermatol Venereol 2008; 22:223-8.

107. Hodeib A, El-Samad ZA, Hanafy H, El-Latief AA, El-Bendary A, Abu-Raya A. Nerve growth factor, neuropeptides and cutaneous nerves in atopic dermatitis. Indian J Dermatol 2010; 55:135-9.

108. Cicek D, Dağlı AF, Aydin S, Baskaya Dogan F, Dertlioğlu $\mathrm{SB}$, Uçak H, et al. Does hepcidin play a role in the pathogenesis of aphthae in Behçet's disease and recurrent aphthous stomatitis? J Eur Acad Dermatol Venereol 2014; 28:1500-6.

109. Aydin F, Kara N, Senturk N, Gunes S, Canturk MT, Bagci H, et al. Lack of association between leptin G2548A gene polymorphism and Behçet's disease. J Eur Acad Dermatol Venereol 2007; 21:68-71.

110. Gorpelioglu C, Erdal E, Ardicoglu Y, Adam B, Sarifakioglu E. Serum leptin, atherogenic lipids and glucose levels in patients with skin tags. Indian J Dermatol 2009; 54:20-2.

111. El Safoury OS, Abdel Hay RM, Fawzy MM, Kadry D, Amin IM, Abu Zeid OM, et al. Skin tags, leptin, metabolic syndrome and change of the life style. Indian J Dermatol Venereol Leprol 2011; 77:577-80.

112. Cicek D, Demir B, Erden I, Kuloglu T, Ucer O, Aydin S, et al. Ghrelin in the pilosebaceous unit: alteration of ghrelin in patients with acne vulgaris. Eur J Dermatol 2015; 25:323-8.

113. El Safoury O, Fawzi M, Abdel Hay RM, Hassan AS, El Maadawi Z, Rashed L. Increased tissue leptin hormone level and mast cell count in skin tags: a possible role of adipoimmune in the growth of benign skin growths. Indian J Dermatol Venereol Leprol 2010; 76:538-42.

114. Liu J, Li J, Zhai N, Geng L, Song F. Detection of the levels of neuropeptides, ACTH and cortisol in the blood of patients with polymyositis/dermatomyositis and their significance. J Dermatol 2004; 31:392-7.

115. Aydin S. A short history, principles, and types of ELISA, and our laboratory experience with peptide/protein analyses using ELISA. Peptides 2015; 72:4-15. 